\title{
THE END OF ALL THINGS: \\ Geomateriality AND DEEP TIME
}

\author{
EL FINAL DE TODAS LAS COSAS: \\ GEOMATERIALIDAD Y TIEMPO PROFUNDO
}

\begin{abstract}
The world, as a unifying nexus of significance, is inherently precarious and constitutively destined toward its own unraveling. Our fascination with a future end of the world masks our realization that the world as common and unified totality is already disintegrating. What remains after the end of the world is also what precedes it, the geomaterial elements, which condition the world without being reducible to things within it. Through our participation in elemental materiality, we encounter the abyssal vertigo of deep time as an anachronistic rupture of lived and historical time. The geological memory of stone situates it at the threshold of world and non-world, while our liability to an immemorial prehistory situates us at the intersection of incommensurable durations, those of the ancestral past as well as the apocalyptic future.
\end{abstract}

Keywords: World. Apocalypse. Elements. Stone. Geology. Speculative. Realism. Deconstruction. Ancestrality. Memory. Husserl. Heidegger. Merleau-Ponty. Derrida. Nancy. Meillassoux.
Ted Toadvine

The Pennsylvania State University

tat30@psu.edu

\begin{abstract}
Resumen: El mundo, como un nexo de significado unificador, es intrínsecamente precario y está constitutivamente destinado a su propio desenredo. Nuestra fascinación por un futuro final del mundo enmascara nuestra comprensión de que el mundo como totalidad común y unificada ya se está desintegrando. Lo que queda después del fin del mundo es también lo que lo precede, los elementos geomateriales, que condicionan el mundo sin ser reducibles a las cosas dentro de él. A través de nuestra participación en la materialidad elemental, nos encontramos con el vértigo abismal del tiempo profundo como una ruptura anacrónica del tiempo vivido e histórico. La memoria geológica de la piedra lo sitúa en el umbral del mundo y del no mundo, mientras que nuestra responsabilidad ante una prehistoria inmemorial nos sitúa en la intersección de duraciones inconmensurables, tanto del pasado ancestral como del futuro apocalíptico.
\end{abstract}

Palabras clave: Mundo. Apocalipsis. Elementos. Piedra. Geología. Especulativo. Realismo. Deconstrucción. Ancestralidad. Memoria. Husserl. Heidegger. Merleau-Ponty. Derrida. Nancy. Meillassoux.

Allow me to begin with a few words of gratitude, first to the Directors of the Center for Advanced Research in Phenomenology for their invitation to deliver 
the Aron Gurwitsch Memorial Lecture, which is now in its 35th year ${ }^{1}$. I have also long felt a particular gratitude to Aron Gurwitsch himself. As someone who first discovered phenomenology through Merleau-Ponty, I appreciate the influence of Gurwitsch's thought and teachings on Merleau-Ponty's philosophical formation, even if Merleau-Ponty himself rarely acknowledged this debt. While reading Phenomenology of Perception in 1947, Gurwitsch wrote to Alfred Schutz of his pleasure at recognizing so much from his lectures in Merleau-Ponty's excellent book, of being in a sense its "godfather", but also of his disappointment that he would not have such an influence in the United States, where everything that he does goes, as he puts it, "into the void" (Grathoff 1989, 93). Of course, nothing could be further from the truth, since Gurwitsch's subsequent students at the New School have played a decisive role in the dissemination of phenomenology in the United States, which is the second reason for my gratitude to him. One of those students, Lester Embree, was my mentor during a postdoctoral fellowship exactly twenty years ago, in 1996, and at the end of my time working with him, he presented me with the gift of a stately desk that Gurwitsch had given to him during his student years, and that Gurwitsch had in turn received from his mentor Kurt Goldstein. I still treasure this desk, my "phenomenology desk", and I like to think of its well-worn surface as imprinted with the memories of these inspiring thinkers.

Nevertheless, I cannot shake the feeling that my gratitude is tinged with an inescapable element of ingratitude, given how little my philosophical approach has in common with Gurwitsch's own, and in this regrettable sense my "memorial" lecture is not genuinely true to his memory. Husserl once told Gurwitsch that they were both "destined to work at the foundations". I have tried in my own fashion to do just this, while acknowledging that what this means for me will have been something quite different than it meant to Gurwitsch himself. The foundations that I will begin from today are the limits of the world, time, and materiality: dust, death, and stones.

\footnotetext{
${ }^{1}$ This essay was delivered as the 2016 Aron Gurwitsch Memorial Lecture at the Society for Phenomenology and Existential Philosophy, Salt Lake City, 21 October 2016.
} 


\section{INTRODUCTION: WHAT COMES AFTER THE WORLD?}

Phenomenology's most significant legacy may well be its thematization of the world as a philosophical problem, which has taught us to understand the world not merely as a given totality of entities or events -our planet, for example, or the universe more broadly- but rather as the non-thematic referential or horizonal structure that the appearance of anything whatsoever presupposes. Phenomenology therefore opens a path for describing the world that is distinct from either the Kantian treatment of it as an a priori form correlated with consciousness or the speculative metaphysical effort to account for the world in terms of another being or another world -both of which fall back on an explanation of the world in worldly terms, by way of what the world alone makes possible. This is why Eugen Fink, in his famous 1933 Kanstudien article, describes phenomenology's task as the effort to uncover "the origin of the world", an origin that could neither be anything within the world, outside of the world, nor in another world (1933, 38/1970, 95). According to Fink, this strange logic of the origin is the key to phenomenology's distinctive understanding of the transcendental, although it also leads to a series of well-known paradoxes that concern how this logic can be communicated or understood in relation to that of worldly beings. Jacques Derrida's early work takes its inspiration from these paradoxes, as Leonard Lawlor has shown, so that deconstruction may also be understood as a radicalization of the problem of world and its genesis ${ }^{2}$.

We will return to the question of the origin of the world, but first let us consider instead the end of the world and, more precisely, what comes after it. In an essay on "World as Horizon" drafted a few months after the horrific events of September 11th, Donn Welton explains the phenomenological sense of world -which he describes as a "nexus of significance" distinct from "something like a natural environment or a socio-historical reality or the totality or whole of all such worlds"- with reference to the collapse of the Twin Towers of the World Trade Center (Welton 2003, 223f). He describes the initial shock caused by the news of the first plane hitting the tower as an example of "dissonance" -a recalcitrant and inexplicable event, though one still occurring against the background of a stable and familiar world, still teleologically oriented toward unity and integration.

\footnotetext{
2 See Lawlor 2002, especially Chapter One, "Genesis as the Basic Problem of Phenomenology".
} 
With images of the second plane being crashed intentionally, dissonance gradually gives way to disintegration, so that, in his words, "With the collapse of the second tower the world itself literally flies apart" (ib. 225). As his essay concludes, "it was not a particular fact or a string of facts within the world, but the world itself, the very context and background of our everyday life, that came unraveled on September 11" (ib. 231).

Welton illustrates the horizonal character of the world, as a stable and pregiven nexus teleologically oriented toward unity and harmony, precisely by calling attention to its fragility, its vulnerability to collapse. The world is not guaranteed; it can and does end. Now, we can distinguish, at least formally, between the disintegration of world as a nexus of significance and its material dissolution, that it, the factual destruction of concrete, plaster, glass, paper, furniture, electronics, and human bodies. The world as such does not consist of things and events, but it holds them together, gives them significance, unity, place, duration. When a tool breaks down within the world, Heidegger's famous hammer, the momentary dissonance remains bound within the web of the whole. But when the web itself unravels, does everything material simply vanish? Hardly. We then find ourselves instead awash in the detritus of world, in piles of rubble, decomposing bodies, clouds of dust. Welton does not mention the cloud of toxic dust that blacked out the sun, a cloud visible from the International Space Station, which gradually settled into a three-inch deep layer of fine powder covering every surface for blocks. Despite the singular ecceity of this dust, it cannot but remind us of the miles of cinders that replaced Hiroshima in 1945, or the tons of mud that choked New Orleans in 2005. Dust, cinders, and mud are what is left of the very materiality of the world after the end of the world; they are world's body dissolved, disintegrated, no longer harmonious or unified, no longer forming a whole, a background, a context. After the world, we are confronted by the geomaterial elements, that from which the world is formed and to which it ultimately returns.

Here, I will try to approach this relationship between world and the elements that precede and exceed it from a few different directions, hoping to catch a better glimpse of it by considering, first, in what sense the world is coming to an end, or has perhaps already ended; second, what it means to be "worldless", like a stone; and, third, how this worldlessness makes possible our exposure to deep time, both past and future. In the first section, then, I follow some clues about 
the "end of the world" from Husserl through Levinas and Derrida. These point toward the conclusion that world in the phenomenological sense has its own dissolution as its ultimate condition and horizon; that world has its outside on the inside, so to speak. The second section then considers our situation of worldlessness in relation to that attributed by Heidegger to the stone. Here, we borrow some critical insights from Jean-Luc Nancy, namely, that there is no "the" stone, no stone in general or as such, and that even if a stone does not "have" a world, it nevertheless may be said to "be" a world, as both the "effective exteriority" of other bodies and the areal spacing that grants the world its there. In the third and last section, we turn our attention from the spacing of stones to their memory, that is, to their role in crossing thresholds of world and time. Here I consider the abyssal character of the experience of geological time and respond to Quentin Meillassoux's rejection of any phenomenological account of "ancestrality", the time prior to consciousness or life. Against Meillassoux, I argue that the vertiginous encounter with the deep past and future has its source in the impersonal worldlessness of the elements, which disrupts any correlation between self and world. The timeless memory of stone situates it both within the world and beyond it, at the threshold of world and non-world, and our liability to this minerality situates us at the intersections of incommensurable durations, those of the ancestral past as well as the apocalyptic future.

\section{HAS THE WORLD ALREADY ENDED?}

Welton's description of the events of 9/11 as the "end of the world" reminds us that, alongside phenomenology's interest in the origin of the world, it has also been invested from the beginning in a certain vision of the end of the world. I have in mind, of course, Husserl's famous thought-experiment of world annihilation in paragraph 49 of Ideas I. Husserl introduces this thoughtexperiment as the final and decisive step toward the phenomenological epochē, intended to purify consciousness of the general thesis of the world. Here he describes the "quite conceivable" possibility that our experiences might be so irresolvably conflictual that they "dissolve into illusion", and not "just for us but in themselves" (Husserl 1976, 103/ 1982, 109). Rather than every illusion or conflict resolving itself by pointing toward a greater truth in a more-inclusive whole, experience could imaginably reveal itself to be, in Husserl's words, 
"refractory to the demand that it carry on its positings of physical things harmoniously, that its context might lose its fixed regular organizations of adumbrations, apprehensions, and appearances -in short, that there might no longer be any world" (1976, 103/1982, 109). In this imaginable -though, for Husserl, obviously counter-factual- scenario, the world would be reduced to more-or-less complete chaos. It might, nevertheless, as he points out, still be haunted by the specters of things, in the form of crude and transient "unityformations" that lack the endurance and stability to cohere into genuine physical things in themselves $(1976,103 f / 1982,110)$. This is the debris of the world, the dust of things, neither quite a physical object nor simply nothing at all.

At first glance, Welton's example -although he refers to it as the "end of the world"- is not comparable with the world-annihilation described by Husserl. At best, this was the end of " $a$ " world, a disintegration of world localized in space and time, not the end of "the" world. The dust that once blocked out the sun has been subjected to analysis by toxicologists, and whether it was the cause of higher cancer rates among first responders is an ongoing topic of legal debates. Even if we might grant that the world as-a-whole looks different to us now, that the world has been irreversibly transformed by this event, the one world as such retains its integrity. But things are not so simple, since we must also ask for whom? If the world has been reconstituted, reintegrated, cleaned up and put back to work, this is so only for the survivors. And how to separate survivors from victims, those whose worlds recovered from those whose worlds remained in tatters, is not obvious if we consider the sufferers of Post-Traumatic Stress, those who continue to mourn lost loved ones, or those who have subsequently perished from exposure to toxic dust. At a phenomenological level, this raises the question of how much irresolvable conflict, how much illusion, the world can tolerate and still be called "the" world, still hang together as a whole from which we can expect a teleological progression toward the truth. Is there, after all, only one decisive end of the world, or might it slowly unravel or even end repeatedly, perhaps even constitutively?

Let us consider two responses to Husserl's thought experiment that address these questions, the first from Levinas and the second from Derrida, with an eye toward what they might teach us about what comes after the world. Writing in 1984, at the height of the second Cold War, Levinas offers the following reflections on Husserl's thought-experiment: "[D]oubtless, the seventy years 
which separate us from Husserl's text -two world wars, totalitarianisms of the right and left, massacres, genocides, and the Holocaust- have already signified (if one can still speak meaningfully) an experience torn to shreds, one impossible to put back together" (Levinas 1990, 12). For Levinas, "our epoch" is characterized by the fact that Husserl's "epistemic reflection"-carried out, as it was, before the outbreak of World War I, and therefore at a time when it might not have been possible concretely to imagine the world "invert[ing] itself into a non-world"-has subsequently taken on an "apocalyptic sense". He names here, in particular, "the nuclear menace which weighs upon our planet, the explosion or universal conflagration that humanity stands in fear of tomorrow", which would be, in his view, the literal enactment of what Husserl had imagined (ib. 12f). World as an intelligible whole, as an object for our self-conscious contemplation and technological manipulation, has therefore long been unraveling and now teeters on the brink of its inversion into a non-world populated by non-things. Furthermore, on Levinas's view, this apocalyptic situation is inseparable from modernity's drive toward mastery of the world, from its attempt to grasp all otherness as a unified whole under the "universal gaze of knowledge". The futile effort of the transcendental "I think" to "reassemble the fantastic images of the real into a world" are therefore less a philosophical failure than a "cosmic catastrophe". In short, apocalyptic destruction is the very culmination of the phenomenological conception of the world, insofar as this is bound up with the modernist techno-scientific agenda through its privileging of transcendental subjectivity.

Alongside this response from Levinas, consider Derrida's claim, made repeatedly in his later work, that each and every death of a unique living thing is the end of the world, absolutely and infinitely, and not merely the end of a world or of a living thing within the world. Derrida makes this point forcefully in his essay "Rams", where it introduces his reading of Celan's poem "Vast, Glowing Vault", and especially its final line: Die Welt ist fort, ich muß dich tragen, "The world is gone, I must carry you". As Derrida writes:

For each time, and each time singularly, each time irreplaceably, each time infinitely, death is nothing less than an end of the world. Not only one end among others, the end of someone or of something in the world, the end of a life or of a living being. Death puts an end neither to someone in the world nor to one world among others. Death marks each time, each time in defiance of arithmetic, the absolute end of the 
one and only world, of that which each opens as a one and only world, the end of the unique world, the end of the totality of what is or can be presented as the origin of the world for any unique living being, be it human or not. (Derrida 2003, 23/2005, 140)

Derrida's insistence here that every death-and he is explicit elsewhere that this should extend even to insects, protozoa, and plants ${ }^{3}$-is the "absolute end of the one and only world" is intended to respect the incommensurability and inappropriability of the other as a singular origin of existence, with a unique and untranslatable exposure to experience and time, a respect that Derrida finds already implied by Husserl's recognition that the other can be presented only through analogical appresentation rather than direct perception.

Furthermore, as Derrida makes explicit in the closing pages of his essay, this way of understanding the end of the world is intended precisely as a way of pushing to its limit Husserl's own thought-experiment of world-annihilation in paragraph 49 of Ideas I. "Isn't this retreat of the world", Derrida asks, "the most necessary, the most logical, but also the most insane experience of a transcendental phenomenology?" (2003, 74/2005, 160). As Derrida notes, Husserl's hypothesis "does not threaten, by right and in its meaning, the sphere of phenomenological and pure egological experience. On the contrary, it would open access to this sphere", and, on his reading, Celan's poem "repeats without weakening this phenomenological radicalization. It pushes to the limit this experience of the possible annihilation of the world and of what remains of the world or still survives it, to wit, its sense 'for me,' for a pure ego" (2003, 75/2005, 161). This is a first step, then: The world is gone. "No world can any longer support us, serve as mediation, as ground, as earth, as foundation or as alibi" $(2003,68 / 2005,158)$. But this brings us, in a second step, to what Derrida calls the most "worrisome test" of Husserlian phenomenology, which is that -once the world is gone, once we find ourselves in the "absolute solitude of the pure ego"then "the alter ego that is constituted in the ego is no longer accessible in an originary and purely phenomenological intution", but is instead "constituted only

\footnotetext{
3 This is most explicit in the January 10, 2001 session from Derrida's death penalty seminar, where he writes that "the death one makes or lets come in this way is not the end of this or that, this or that individual, the end of a who or a what in the world. Each time something dies, it's the end of the world. Not the end of a world, but of the world, of the whole of the world, of the infinite opening of the world. And this is the case for no matter what living being, from the tree to the protozoa, from the mosquito to the human, death is infinite, it is the end of the infinite. The finitude of the infinite" (Derrida 2015, 118f; quoted in Naas 2015, p. $181 \mathrm{n} 14$, who provides this translation).
} 
by analogy, by appresentation, indirectly, inside of me" $(2003,76 / 2005,161)$. I must carry you, but precisely in the most paradoxical sense, where "to carry" no longer means "to include, to comprehend in the self, but rather to carry oneself or bear oneself toward the infinite inappropriability of the other, toward the absolute transcendence in the very inside of me, that is to say, in me outside of $\mathrm{me}^{\prime \prime}(2003,76 / 2005,161)$. The infinite distance that the other's transcendence opens within my world announces my responsibility to carry the other's world within me, to mourn it, after the other's death-but also the melancholic impossibility of my doing so, precisely since I can never contain or encompass this unique and singular opening onto the world. And this ethical moment, the paradoxical responsibility to carry the other, requires the withdrawal of the world, in the sense of any common ground or foundation that might serve to mediate between us. The survivor is left "in some fashion beyond or before the world itself [...] responsible without world (welt/os), without the ground of any world, thenceforth, in a world without world, as if without earth beyond the end of the world" (2003, 23/2005, 140).

Now, although Derrida begins from the death of the other, the end of the world as he is describing it does not, strictly speaking, await an actual death. This is because each and every encounter with each and every living thing already announces the heart of absence or transcendence interrupting and constituting my world, calling me to respond with a mourning both ineluctable and insufficient. The end of the world therefore haunts every world from within, contesting its pretense of being "one and only", "unique", or an all-encompassing horizon. If the end of the world is already implicated within and even constitutive of the world itself, then the world is not a self-enclosed totality that maintains itself until interrupted from the outside, but rather has its outside on the inside.

Derrida returns to this investigation of the end of the world and radicalizes it further in the second year of his final seminar, The Beast and the Sovereign, this time in dialogue with Heidegger's famous three theses on world from Fundamental Concepts of Metaphysics-the stone is worldless (weltlos), the animal is poor in world (weltarm), and man is world-forming (weltbildend) 4 . Derrida frames the year's seminar in the first lecture with three theses of his own, three thesis that are apparently incompatible with each other, briefly

\footnotetext{
${ }^{4}$ See Heidegger 1992: 272ff; 1995: $184 f f$.
} 
summarized as follows: (1) animals and humans incontestably inhabit the same "objective" world, even if they do not have the same experience of "objectivity"; (2) animals and humans incontestably do not inhabit the same world, since the human world is not identical with that of non-human animals; and (3) no two individuals, whether human or animal, inhabit the same world, and the differences between their worlds are essentially unbridgeable. This third thesis follows from the fact that "the community of the world is always constructed, simulated by a set of stabilizing apparatuses, more or less stable, then, and never natural, language in the broad sense, codes of traces being designed, among all living beings, to construct a unity of the world that is always deconstructible, nowhere and never given in nature" (2010, 31/2011, 8f). Between my world (which, for me, can only be the unique and only world, encompassing all others) and the world of any other, therefore, "there is first the space and the time of an infinite difference, an interruption that is incommensurable with all attempts to make a passage, a bridge, an isthmus, all attempts at communication, translation, trope, and transfer that the desire for a world or the want of a world, the being wanting a world will try to pose, impose, propose, stabilize. There is no world, there are only islands" (2010, 31/2011, 9).

Derrida returns to the first and third of these theses in the tenth and final session of the seminar, where he again emphasizes, developing the third claim, that the unity of the world is a merely presumptive construction, a means of reassuring ourselves in the face of the absence of the world. Here, the end of the world-again associated with the line from Celan, "Die Welt ist fort"-does not await the death of the other but is instead "the ever unsewn and torn tissue of our most constant and quotidian experience", something that we know "with an undeniable and stubborn, i.e., permanently denied, knowledge" (2010, $367 / 2011,266)$. The presumptive unity of the word "world", then, is intended to

mask our panic [...], to protect us against the infantile but infinite anxiety of the fact that there is not the world, that nothing is less certain than the world itself, that there is perhaps no longer a world and no doubt there never was one as totality of anything at all [...] and that radical dissemination, i.e. the absence of a common world, the irremediable solitude without salvation of the living being, depends first on the absence without recourse of any world, i.e. of any common meaning of the word "world", in sum of any common meaning at all. (Derrida 2010, 366/2011, 265f)

Here, we have moved from treating the end of the world as a phantasm to Investigaciones Fenomenológicas, vol. Monográfico 7, 2018 
recognizing that the phantasm is actually the world itself, that the phantasm of the world is intended to mask the absence of any common world. Our anxieties about the end of the world, insofar as they present the world as fragile and vulnerable, precisely reinforce our belief in its reality. In this situation, according to Derrida, I must carry you can mean one of only two things: either that, with both of us sharing this knowledge that the world is no longer, I must carry you into the worldless void; or, that what I must do, "with you and carrying you, is make it that there be precisely a world, just a world, if not a just world, or to do things so as to make as if there were just a world, and to make the world come to the world..." (2010, 369/2011, 268). On Michael Naas's reading, Derrida places his hope in the second option, which Naas describes as a poetic making or remaking of the world ex nihilo in full recognition that there is no world: "Aware of its own powerlessness, undone by its own ability, this poiesis would be a making as if that leaves within the world a trace of the end or loss of the world" (Naas 2015, 60). Without a poetic making or remaking of the world, a making of the world with and for the other, we remain weltlos, worldless, like the stone.

Nevertheless, Derrida's final seminar suggests another reconstructive path for understanding the world, namely, in the first of the three theses introduced in the first session: "animals and humans inhabit the same world, the same objective world" $(2010,31 / 2011,8)$; as living beings, they share in common "the finitude of their life, and therefore, among other features of finitude, their mortality in the place they inhabit, whether one calls that place world or earth (earth including sky and sea) and these places that they inhabit in common [...]" $(2010,33 / 2011,10)$. When Derrida returns to this common sense of world in the final session, he again stresses that it is the same space of inhabitation or cohabitation, a common habitat, characterized precisely in terms of the elements: "water, earth, air, fire" $(2010,363 / 2011,263)$. Now, this returns us the problem of the elements and their ambivalent relationship with world. We have seen how the elements are left behind with the world's dissolution, such that the disintegration of our buildings and tools into dust figures the world's absolute reference to its finitude, its liability to the arche-materiality that grants its endurance and holds its horizons open. If the world has its outside on the inside, if it bears an essential reference to its own dissolution as its fundamental condition and ultimate horizon, then this liability is figured in its paradoxical relation to the elements, as neither precisely things within the world nor wholly 
outside it. Derrida's remarks here suggest that the elements, while remaining liminal to world in the phenomenological sense, nevertheless open a space and time that traverses all worlds.

\section{TOUCHSTONES}

Derrida notes at several points that the departure of the world, Die Welt ist fort, exceeds and disrupts Heidegger's three thesis on world, that its irreducibility to the categories of weltlos, weltarm, and weltbildend requires us to rethink the very thought of world (2003, 79/2005, 163; cf. Derrida 2010, 159, 243/2011, $104,169)$. Nevertheless, even if our situation of carrying the other is irreducible to either of these categories, Derrida repeatedly describes it using Heidegger's category for the worldless stone, "We are weltlos" $(2010,31 \mathrm{f} / 2011,9)^{5}$. Of course, we are "clearly not" worldless in the same manner as Heidegger had attributed this to the stone, as Derrida says explicitly $(2010,32 / 2011,9)$, but then how are we to think this strange lithic proximity? Recall that, for Heidegger, the stone is "absolutely indifferent" insofar as it remains entirely outside or before the difference between being indifferent or not indifferent to its own being (Derrida 1987, 39ff/1989, 20f); it is neither awake nor asleep (Derrida 2006, $203 / 2008,148)$; it cannot be deprived of world since it has absolutely no relationship with other entities, no experience of the sun that shines upon it or the lizard that rests atop it (Derrida 1987, 79ff/1989, 51f; cf. Derrida 2006, 213/2008, 155f). Furthermore, and for Heidegger this is the Prüfstein, the touchstone (Derrida 2010,115/2011, 173), the stone "does not die, because it does not live" (2010, 171/2011, 113; cf. Derrida 2006, 211/2008, 154); it is finite while lacking finitude $(2006,206 / 2008,150)$, and therefore entirely outside of the relation between life and death, of mortality or lifedeath.

Derrida calls attention to the fact that, in Heidegger's theses on world, the stone stands in as the sole example of "material things", of the "lifeless" or the "inanimate". As Derrida asks "Why does he take [this] example of an inanimate thing, why a stone and not a plank or a piece of iron, or water or fire?" (2010, 27f/2011, 6; cf. Derrida 2006, 209/2008, 153). By privileging "the" stone as exemplary of the material thing, Heidegger participates in what Jeffrey Cohen

${ }^{5}$ See also Derrida 2003: 23/2005: 140; 2010: 253/2011: 177. 
calls "a long tradition of mining the philosophical from the lithic", which poses the question of what stone's ontological exemplariness reveals as well as conceals (Cohen 2005, 4). For Derrida, the choice of the stone as exemplar serves to cover over the ambiguities of the concept of life, which become obvious when one considers where to locate plants, for example -or cadavers- in relation to the general categories of "life" or "material things" (2010, 28/2011, 6). But in attending here only to the complications of any pure distinction between what is inside or outside of lifedeath, Derrida never addresses-as he does so well with the general category of "the" animal-the fact there can be no the stone, no general category of "stone". This is so, first of all, because there is no "the" material thing, no material thing in general, but only a plurality of material singularities. As Jean-Luc Nancy puts this point, matter is "always singular or singularized" (1993, 97/1997, 58), the very difference and différance "through which something is possible, as thing and as some" (1993, 95/1997, 57). Furthermore, there is no stone in general or as such, but rather pebbles, stones, rocks of unimaginably diverse sorts, sizes, and placements, each one singularly unique. And even if Heidegger is correct to insist that no stone "has" a world, each singularly unique stone may nevertheless constitute a manner of beingtoward, of l'être-à, that, according to Nancy, qualifies it as a world. As Nancy writes: "To be sure, the concrete stone does not 'have' a world [...] but it is nonetheless toward or in the world [au monde] in a mode of toward or in that is at least that of areality: extension of the area, spacing, distance, 'atomistic' constitution. Let us say not that it is 'toward' or 'in' the world, but that it is world" (1993, 103/1997, 62, cf. 1993, 48/1997, 28). The originary spacing of every stone, as a world of its own, would therefore be what Nancy calls the "effective exteriority" of all else that exists. In response to Heidegger's three theses on world, Nancy writes: "These statements do not do justice, at least, to this: that the world beyond humanity -animals, plants, and stones, oceans, atmospheres, sidereal spaces and bodies- is quite a bit more than the phenomenal correlative of a human taking-in-hand, taking-into-account, or taking-care-of: it is the effective exteriority without which the very disposition of or to sense would not make $[\ldots]$ any sense" $(1993,92 / 1997,55 f)$. The stone is both a part of the world and also, as its effective exteriority, constitutive of the there, the spacing and material singularity, of the world. While Nancy is no doubt correct to emphasize each and every stone's spacing and singularity, what truly distinguishes each 
stone and accounts for its liminal relationship with world is its peculiar relationship with time, especially geological or "deep" time, both past and future.

\section{Geological MEMORY}

In a posthumous 1805 biographical sketch of James Hutton, often referred to as the founder of modern geology, his friend John Playfair recounts their 1788 trip to Siccar Point, on the east coast of Scotland, to view a geological formation that has since become known as Hutton's Unconformity (Playfair 1822, 71ff). At this site, erosion had made clearly visible the juxtaposition of horizontal strata of red limestone with underlying nearly vertical columns of greywacke. The scientists' interest with this formation was due to what it implied about the incredible expanse of time required for its generation, the patiently slow and sequential accumulation of each layer of rock compounded by the folding over of older millennia of deposited strata into their own perpendicular layer below. For Hutton, this scene provided incontrovertible evidence of his theory of uniformitarianism, according to which the geological past must be explained by the same gradual processes of sedimentation and erosion operating today, leading him to propose a concept of geological time with "no vestige of a beginning, -no prospect of an end" (Hutton 1788, 304). Nowadays, geologists studying Hutton's Unconformity date the lower layer of Silurian greywacke at around 435 million years old, and the upper layer of Devonian sandstone at 370 million years, with the seam of the unconformity marking a 65 million-year hiatus of "missing" time. Certainly these numbers astound none of us today in the way that they did Hutton's contemporaries; we are all perfectly familiar with the general concept, if not the particulars, of the geological timescale and with linear representations of the age of the earth that indicate the emergence of Homo sapiens at the fractional tail-end of a long temporal comet. But can we truly say, even today and with our extensive theoretical knowledge of geological time, that we comprehend the scales of time involved?

Hutton's Unconformity is to geologists what the Galapagos Islands are to biologists, and references to it rarely miss the opportunity to mention Playfair's famous retrospective account of his trip with Hutton, with its invocation of the temporal sublime: 
We felt ourselves necessarily carried back to the time when the schistus on which we stood was yet at the bottom of the sea, and when the sandstone before us was only beginning to be deposited, in the shape of sand or mud, from the waters of a superincumbent ocean. An epocha still more remote presented itself, when even the most ancient of these rocks, instead of standing upright in vertical beds, lay in horizontal planes at the bottom of the sea, and was not yet disturbed by that immeasurable force which has burst asunder the solid pavement of the globe. Revolutions still more remote appeared in the distance of this extraordinary perspective. The mind seemed to grow giddy by looking so far into the abyss of time; and while we listened with earnestness and admiration to the philosopher who was now unfolding to us the order and series of these wonderful events, we became sensible how much farther reason may sometimes go than imagination can venture to follow. (Playfair 1822, 80f)

While geological theories since Hutton's time have undergone the same tumultuous upheavals that he ascribed to this ancient sea bed, the abyssal and vertiginous experience of geological time remains contemporary. The ground beneath our feet is scarcely reassuring as we try to wrap our minds around the breakup and reassembly of the earth's continents, the cornucopia of longvanished species that flourished in worlds we can scarcely reconstruct, or the billions of years that light has traveled from distant galaxies to reach our eyes. This is not just meganumerophobia, a fear of very large numbers; we encounter the abyssal unfathomability of time affectively and viscerally, in our heart of hearts, like a wedge driven through our lived experience of daily rhythms, our personal memories and anticipations, and the historical fabric of cultural events. Indeed, the very "depth" of geological time is the bottomless free-fall into which it throws all markers and touchstones by which we orient ourselves within the temporal horizons of our world.

For Hutton, there was no prospect of a beginning to geological processes, but today we rely on radiometric dating, based on the constant rate of decay of trace radioactive elements, to estimate the Earth's age at around 4.5 billion years. The samples used for such dating are paradigmatic of what Quentin Meillassoux, in After Finitude, has termed "arche-fossils", material traces of an "ancestral" reality or event "anterior to the emergence of the human species -or even anterior to every recognized form of life on earth" (2006, 25f/2008, 10). According to Meillassoux, the literal truth of empirical claims about such an ancestral reality cannot be admitted by post-Kantian "correlationism", the dominant ideology 
according to which thinking and being may only be understood in their correlation and never independently of each other. For the correlationist-and Meillassoux seems to have phenomenologists primarily in mind-statements about such an ancestral time, a time prior to all manifestation, are strictly meaningless. But this leaves us, Meillassoux argues, with a "strange feeling of imprisonment or enclosure", insofar as the only exteriority that we can encounter remains relative to thought $(2006,21 / 2008,7)$. And so, what correlationism has lost, and what Meillassoux's speculative materialism claims to recover, is, in his words, "the great outdoors, the absolute outside of pre-critical thinkers: that outside which was not relative to us, and which was given as indifferent to its own givenness to be what it is, existing in itself regardless of whether we are thinking of it or not" $(2006,21 \mathrm{f} / 2008,7)$. This absolute Outside would no longer be the correlate of any subject; in its absolute indifference to subjectivity, it would no longer reflect back to us our own involvement and inherence in the world.

Now, although Meillassoux does not present his view in these terms, he is clearly concerned with the end of the world, at least of the world as we know it. This is why he begins his argument with the "ancestral", with reality "anterior to every recognized form of life on earth" $(2006,25 f / 2008,10)$ and later pairs this with "possible events that are ulterior to the extinction of the human species" (2006, 155/2008, 112), such as would be entailed, he says, by "hypotheses about the climactic and geological consequences of a meteor impact extinguishing all life on earth" (2006, 155f/2008, 112). The Outside, for Meillassoux, always has the air of apocalypse. This is the case despite the fact that the absolute Outside is not only anterior or ulterior to our world, but also absolutely exterior to us in the present, as a kind of mathematical dopplegänger of our world defined by its radical indifference to human existence (2006, $160 / 2008$, 116). Beyond the horizons of our world, as its Great Outside, this "world without us" presumably does not touch on our lived world in any way other than to haunt it from the fringes.

Just as Meillassoux trades on our everyday notion of world, so he fails to thematize the problem of time, which for him seems to be reducible to a formula for designating the properties of an event, much as it would be, in his example, for a scientist using thermoluminescence to date the light emitted by stars. What requires explanation, on his account, is the truth of such scientific conclusions about the "date" of pre-human events, or the "age" of the universe, and such 
dates are designated by numbers on a line $(2006,24 / 2008,9)$. Furthermore, the problem of how to understand these numbers and this line first confronts us only in the era of modern science, since for him the ancestral past is a past that we come to know primarily or exclusively through scientific investigation (2006, $39 / 2008,28)$. But clearly scientific research makes no claim to explain what is meant by "past", nor can it do so, since it takes for granted our lived, prescientific experience of time (Merleau-Ponty 2003a, 171f/2010, 128). If the geological scale of time means anything more to us than numbers on a line, this is because our experience opens us to a past, and even to an incomprehensibly ancient prehistory. It does so because, as Merleau-Ponty emphasizes in his reading of Whitehead, we are ourselves embedded, mind and body, within the temporal passage of nature; its pulsation runs across us (Merleau-Ponty 1995, $159 \mathrm{ff} / 2003 \mathrm{~b}, 117 \mathrm{ff})$. And this pulsation transcends the past-present distinction in such a way that past and present are enveloping-enveloped, Ineinander, each moment entering into relations of exchange and identification, interference and confusion, with all the others (Merleau-Ponty 1964, 321/1968, 267f; 2003a, $36 / 2010,7)$. This is why Merleau-Ponty identifies time as the very model of institution and of chiasm (2003a, 36/2010, 7; 1964, 321/1968, 267), and calls nature the "Memory of the world" (1995, 163/2003b, 120; 1964, 247/1968, 194). On the one hand, this leads Merleau-Ponty to reject any time "in itself" that would be entirely purified of any point of view, since we cannot think time apart from our own emergence within it and our subsequent reconstruction of it. On the other hand, it entails no reduction of time to a correlate of thought, since institution here is nearly the opposite of constitution: whereas "the constituted makes sense only for me", as Merleau-Ponty puts it, "the instituted makes sense without me" (2003a, 37/2010, 8). Simply put, just as institution is nearly the opposite of constitution, chiasm is nearly the opposite of correlation.

Meillassoux's critique of the correlationist position relies on the understanding of geological scales of time first opened by scientists such as Hutton. But, interestingly, Hutton's Unconformity does not precisely qualify as an arche-fossil in Meillassoux's sense: the Silurian seas were teaming with life, and forests were already spreading across the continent of Laurasia by the late Devonian Period. A true arche-fossil must point back more than 4.1 billion years to precede the earliest fossil evidence of life on earth (which, of course, does not rule out life's existence elsewhere in the cosmos). Meillassoux takes no account, then, of deep 
time's distinctive stratigraphic rhythms-cosmic, geological, evolutionary, prehistoric-nor the ways that these affectively involve us in differential ways. In fact, Meillassoux's invocation of ancestrality, despite its reliance on a scientific understanding of deep time, never recognizes the intensely interruptive and disorienting character of abyssal and immemorial time. He cannot do so, since his view sunders reality into two worlds and two times, one correlated with subjectivity, and the other describable only in mathematical terms. What Meillassoux misses is precisely the chiasm between lived time and natural time that makes any genuine encounter with the immemorial possible, and this is linked to his failure, throughout After Finitude, to thematize the problems of world and materiality on which his view depends. More generally, in his single-minded effort to avoid the co- of correlationism, Meillasoux fails to grasp the chi, the chiastic intertwining that is constitutive of materiality, world, and time.

What characterizes the experience of the deep past is precisely its unsettling, vertiginous character, the loss of all common markers and measures. It is our ability to open onto a past that was never our own possibility, never our own memory-an impossible and immemorial past-that makes any scientific investigation or mathematical representation of such a past possible. Now, it is only through phenomenology that we can investigate this impossible memory, a memory that belongs to the elements rather than to us. In short, the ancestral past is indeed meaningful within our lived, pre-scientific experience of time-and, furthermore, the deep evolutionary, geological, and cosmic dimensions of the past gain their true sense only in relation to experience.

Through this lens, we can see that the many analyses of the "anonymity" of the body that Merleau-Ponty develops in Phenomenology of Perception concern our liability to a forgotten past, here at the level of organic life. The "someone" within me who is the agent of my sensing body, and who is distinct from the personal self of my reflective consciousness, lives, he says, in a "prehistory", the "past of all pasts", which is the time of our organic rhythms, such as the beating of the heart $(1945,277,293,100 / 2012,250,265,87)$. Merleau-Ponty refers to this cyclical time as "the time of nature with which we coexist", an "absolute past of nature" incommensurate with the narrative, linear time of the personal self $(1945,517,160 / 2012,479,139)$. One dimension of this "absolute past of nature" is our own biological life, our animality, insofar as this is lived as an anonymous and immemorial past in relation to the narrative history of our 
personal lives. Since this past is anterior to the distinction between subject and object, or between human and nonhuman, anonymous sensibility cannot be a conscious experience; it cannot occur within personal time, the time of reflection, insofar as it makes such time possible. Sensibility as an organic inheritance is therefore the generative ground of experience, even as it remains for each of us, in our reflective lives, a past that has never been present ${ }^{6}$. It is due to the lateral kinship of this organic prehistory that other animals speak through our voices and gaze out through our eyes? ${ }^{7}$.

The sensibility, sedimented habits, and organic rhythms of our bodies offer the most proximal and constant encounter with the immemorial past -by which I mean an anonymous and asubjective prehistory that haunts and conditions every present, without this past ever having been present for me. And yet this organic time of the body does not exhaust the dimensions of the immemorial past. In sensibility, I not only reenact my own animality, but I also, through my participation in the elementality of things, take up at the heart of my existence the entire history of the universe. The phenomenological encounter with the vertigo of deep time, of which I catch a glimpse in the stone, is the echo within my body of an asubjective time of matter, of an unfathomably ancient passage that haunts the heart of the present. Beyond organic time, we encounter that dimension of our existence that resonates with the pulsation of the geological and the cosmic, that is, with elemental time in its broadest registers.

As a clast of the lithosphere, of the stony planetal skeleton that undergirds any earthly lifeworld, each stone recalls or remembers the elemental geomateriality that precedes and exceeds all worlds. Just as creation stories envision the emergence of the world from formless waters and earth, the raging elements are a recurring motif in our eco-eschatological imagination: rising waters, glaciation, parched sands and storms of dust, hurricanes and earthquakes. "Some say the world will end in fire, some say in ice". Whether by fire or ice, our vision of the end of the world is haunted by its dissolution into elemental materials and forces of sublime scope and scale. As Levinas notes, "the element comes to us from nowhere; the side it presents to us does not determine an object, remains entirely anonymous. It is wind, earth, sea, sky, air" (Levinas 1971, 139/1969,

\footnotetext{
${ }^{6}$ Al-Saji (2008) has fruitfully developed this interpretation of sensibility as the generative past.

${ }^{7}$ I develop this point further in Toadvine 2013.
} 
132). The stone extracted from the elements to become part of the world remains nevertheless inhabited or haunted by this anonymous elementality from which the world is extracted and to which it must inevitably return. This is why our imaginations of the world's end run up against a limit that is, finally, indestructible: the fact that "there is" something, that existence as such continues, perhaps independently of all subjectivity or even all life, if only in elemental form: fire and ice, dust and gas, atomic radiation, the stars.

Stone holds a preeminent place among the elements precisely because of its peculiar temporality, its geological memory. We owe our conception of the deep past to this memory of stone, which Buffon in 1778 could call "the world's archives"; just as we may reconstruct human history from ancient inscriptions and artifacts, so it is possible, he writes, to "extract ancient monuments from the earth's entrails" in order to "place a certain number of milestones on the eternal road of time" (Buffon 1778, 1). This archival memory of stone spans all times and worlds, outstripping and undergirding the literary archive that serves as the objective memory of human cultures. Christopher Tilley (2004) demonstrates how Neolithic menhirs embody the traces of prehistoric perceptual worlds, even as the accumulated geomaterial records of our own lives pass into the far future in the form of nuclear waste, the stratigraphic traces of radioactive elements from nuclear blasts, and fossilized "plastiglomerates"8. This timeless memory of stone situates it both within the world and beyond it, seesawing at its edge, which makes it the ideal boundary marker, milestone, or tombstone. As John Sallis writes:

Stone comes from a past that has never been present, a past unassimilable to the order of time in which things come and go in the human world; and that nonbelonging of stone is precisely what qualifies it to mark and hence memorialize such comings and going, births and deaths. As if stone were a sensible image of timelessness, the ideal material on which to inscribe marks capable of visibly memorializing into an indefinite future. (Sallis 1994, 26)

The stone is always somehow from another world even as it subsists in this one, like a meteor, a fossil, or a glacial erratic, haunted by its immemorial passage across worlds.

Alongside the phantasmic projection of a world in common, a world of shared

${ }^{8}$ On "plastiglomerites", see Corcoran, Moore, and Jazvac 2014. 
meaning that would bridge our separate islands, then, we must take into account the persistent geomateriality that grants existence its areal spacing and its temporal span. This is less a matter of common habitat than of the essential and constitutive lithic materiality of every living being. As Nancy writes, "A stone is the exteriority of singularity in what would have to be called its mineral or mechanical actuality. But I would no longer be a 'human' if I did not have this exteriority 'in me', in the form of the quasi-minerality of bone" $(1996,18 / 2000$, 37; cf. Nancy 1993, 100-102/1997, 60f). Our liability to this minerality is figured in the skeleton as symbol of death, as the endurance of our own lithic elementality into the rhythm of a temporality other than or exceeding that of lifedeath, just as the fossil offers a glimpse of the intersection of the time of life with the immemorial past of stone.

The vertigo of deep time has its source in the disruption of any correlation between self and world, in the impersonal worldlessness of the elements. And here the anonymity of the elements bends around time; it is both the prehistoric, ancestral past and the eternity of an unimaginable future. In short, the time before the world is inseparable from, perhaps indistinguishable from, the time after the world's dissolution. If along one dimension, we are beings-towarddeath, then along another-anonymous and asubjective-dimension, we are beings-toward-the-end-of-the-world, already hearkening to the eternity of silence that waits to swallow all that we are and know and can imagine. "Worldwithdrawal and world-decay can never be undone", Heidegger reminds us (1971, 41); and, we might add, neither can they be deferred. The apocalyptic imagination that obsesses contemporary culture is not a consequence of our technological domination of the planet and ourselves, therefore, but is only made possible by the revelation within our hearts of an impossible future that outstrips every imagination. To truly encounter the very materiality of our own minds and bodies is to fall into the abyss of such elemental time, which means to rediscover it at the kernel of organic and personal time. But our embodied immersion in the Memory of the world tears us apart, scattering us across an incommensurable multiplicity of temporal flows and eddies. We encounter, then, an asubjective time, a time without a world, at the heart of lived time. This worldless prehistorical time, independent of any subject, is precisely the time of the elements, of ashes and dust. The experience of such a mythical "time before time", as Merleau-Ponty tells us, is one that "remembers an impossible past" and "anticipates an impossible future" (1964, 296, 163/1968, 243, 123). This impossible future 
is surely a return to the elements, of dust to dust; in other words, it is the apocalypse to come .

\section{REFERENCES}

AL-SAJI, Alia (2008). "'A Past Which Has Never Been Present': Bergsonian Dimensions in Merleau-Ponty's Theory of the Prepersonal", Research in Phenomenology, Vol. 38, 1: 41-71.

BufFon, Georges (1778). Histoire naturelle des époques de la nature, Paris: De l'Imprimerie Royale.

COHEN, Jeffrey (2015). Stone: An Ecology of the Inhuman, Minneapolis: University of Minnesota Press.

CorCoRAn, Patricia L. / Charles J. Moore / Kelly Jazvac (2014), "An Anthropogenic Marker Horizon in the Future Rock Record", GSA Today, Vol. 24, 6: 4-8.

DeRrIDA, Jacques (1987). De l'esprit, Paris: Editions Galilée.

-, (1989). Of Spirit: Heidegger and the Question, Trans. Geoffrey Bennington / Rachel Bowlby, Chicago: University of Chicago Press.

- (2003). Béliers, Paris: Editions Galilée.

- (2005). Sovereignties in Question: the Poetics of Paul Celan, Ed. Thomas Dutoit / Outi Pasanen, New York: Fordham University Press.

-, (2006). L'Animal que donc je suis, Paris: Éditions Galilée.

一, (2008). The Animal That Therefore I Am, Trans. David Wills, New York: Fordham University Press.

-, (2010). Séminaire: La bête et le souverain. Volume II (2002-2003), Paris: Éditions Galilée.

-, (2011). The Beast and the Sovereign. Volume II, Trans. Geoffrey Bennington, Chicago: Chicago University Press.

-, (2015). Séminaire: La peine de mort. Volume II (2000-2001), Ed. Geoffrey Bennington / Marc Crépon, Paris: Éditions Galilée.

Fink, Eugen (1933). "Die phänomenologische Philosophie Edmund Husserls in der gegenwärtigen Kritik", Kant-Studien, Vol. 38: 319-383.

\footnotetext{
9 This essay incorporates passages from Toadvine (forthcoming) and Toadvine 2014. This material will eventually appear in revised form in my book in progress, The End of All Things: Eschatology and the Elements. 
-, (1970). "The Phenomenological Philosophy of Edmund Husserl and Contemporary Criticism", in The Phenomenology of Husserl, Ed. R. O. Elveton, Chicago: Quadrangle Books, pp. 73-147.

Grathoff, Richard (1989). Philosophers in Exile: The Correspondence of Alfred Schutz and Aron Gurwitsch, 1939-1959, Ed. R. Grathoff, Bloomington: Indiana University Press.

Heidegger, Martin (1971). Poetry, Language, Thought, Trans. Albert Hofstadter, New York: Harper \& Row.

-, (1992). Die Grunbegriffe der Metaphysik. Welt-Endlichkeit-Einsamkeit, Frankfurt am Main: Vittorio Klostermann.

-, (1995). The Fundamental Concepts of Metaphysics, Trans. William McNeill / Nicholas Walker, Bloomington: Indiana University Press.

HUSSERL, Edmund (1976). Ideen zu einer reinen Phänomenologie und phänomenologischen Philosophie. Erstes Buch: Allgemeine Einführungin die reine Phänomenologie, Husserliana 3/1, Ed. Karl Schuhmann, The Hague: Martinus Nijhoff.

-, (1982). Ideas I, Trans. Fred Kersten, The Hague: Martinus Nijhoff.

HUTTON, James (1788). Theory of the Earth, Edinburgh: Royal Society of Edinburgh.

LAWLOR, Leonard (2002). Derrida and Husserl: The Basic Problem of Phenomenology, Bloomington: Indiana University Press.

LeViNAS, Emmanuel $\left(1971^{4}\right)$. Totalité et infini, The Hague: Martinus Nijhoff.

-, (1969). Totality and Infinity, Trans. Alphonso Lingis, Pittsburgh: Duquesne University Press.

-, (1990). "Simulacra: The End of the World", Trans. David Allison, in Writing the Future,Ed. David Wood, London: Routledge, pp. 11-14.

MeILlassoux, Quentin (2006). Après la finitude, Paris: Éditions de Seuil.

-, (2008). After Finitude: An Essay on the Necessity of Contingency, Trans. Ray Brassier, London: Continuum.

Merleau-Ponty, Maurice (1945). Phénoménologie de la perception, Paris: Gallimard.

- (1964). Le visible et l'invisible, Paris: Gallimard.

-, (1968). The Visible and the Invisible, Trans. Alphonso Lingis, Evanston: 
Northwestern University Press.

- . (1995). La nature. Notes. Cours du Collège de France, Paris: Seuil.

—, (2003a). L'institution. La passivité, Tours: Belin.

-, (2003b). Nature: Course Notes from the Collège de France, Trans. Robert Vallier, Evanston: Northwestern University Press.

-, (2010). Institution and Passivity, Trans. Leonard Lawlor / Heath Massey, Evanston: Northwestern University Press.

-, (2012). Phenomenology of Perception, Trans. Donald Landes, London: Routledge.

NAAS, Michael (2015). The End of the World and Other Teachable Moments: Jacques Derrida's Final Seminar, New York: Fordham University Press.

NANCY, Jean-Luc (1993). Le sens du monde, Paris: Éditions Galilée.

—, (1996). Être singulier pluriel, Paris: Éditions Galilée.

-, (1997). The Sense of the World, Trans. Jeffrey Librett, Minneapolis: University of Minnesota Press.

-, (2000). Being Singular Plural, Trans. Robert Richardson / Anne O'Byrne. Stanford: Stanford University Press.

Playfair, John (1822). "Biographical Account of the Late James Hutton, M. D.", in The Works of John Playfair. Vol. 4, Edinburgh: Archibald Constable and Co.

SALLIS, John (1994). Stone, Bloomington: Indiana University Press.

TILLEY, Christopher (2004). The Materiality of Stone: Explorations in Landscape Phenomenology, Oxford: Berg.

ToAdVinE, Ted (2013). "Le temps des voix animals", Chiasmi International. Existence, Diacritics, Animality, Vol. 15: 269-282.

-, (2014). The Elemental Past, Research in Phenomenology, Vol. 44, 2: 262-279.

-, (Forthcoming). Thinking After the World: Deconstruction and Last Things. In Eco-Deconstruction: Derrida and Environmental Ethics, Ed. Matthias Fritsch / Philippe Lynes / David Wood, Bronx: Fordham University Press.

Welton, Donn (2003). "World as Horizon", in The New Husserl: A Critical Reader, Ed. Donn Welton, Bloomington: Indiana University Press, pp. 223-232. 